Ayurlog: National Journal of Research in Ayurved Science

\title{
“To study the efficacy of Bhumyamalaki Mula Choorna on Raktapradara
}

\section{(Menorrhagia)."}

\section{Ankita Ashok Thakur*1, Seema Mehere ${ }^{2}$}

1. P.G. Scholar,

2. HOD \& Guide Of Prasutitantra \& Streeroga.

YMTAyurvedic Medical College, Kharghar, Navi Mumbai., Maharashtra.

*Correspondence author: ankitathakur0201@ gmail.com

\section{ABSTRACT: -}

Pradara due to pradirna (excessive excretion) of raja (menstrual blood), it is called as pradara \& since ,there is dirana( excessive excretion) of asrk (menstrual blood) hence, it is known as asrgdara. Menorrhagia, one of the most frequently encountered symptoms in gynecology, is defined as menstruation periods at regular cycle but with excessive flow which may last more than 7 days. Menorrhagia can cause menstrual bleeding of more than $80 \mathrm{~mL}$ in each cycle. Raktapradara is commonest problem encountered by gynecologist in todays practice \& incidence becomes higher with degree of civilization. Blood tissue is considered as one among 7 dhatu as per Ayurveda. Blood is related with pitta dosha. Hence, bleeding disorders are usually influenced by pitta imbalance. rakta pradara covers all types of menorrhagia. The vауи after getting vitiated, increases quantity of rakta(blood), takes rakta to rajovaha siras $\&$ increases the quantity of rajah that comes out through rajovaha siras \& causes raktapradara. The purpose of this study is to identify menstruation characteristics of the women $\&$ the effect of menorrhagia on womens quality of life. So many preparation have been mentioned in ayurvedic classic for the treatment of raktapradara. All these medication have certain fundamental principles Ayurvedic drug, bhumyamalaki mula choorna with tandulodak (rice water) combination was selected for the study.

$$
\text { In this "TO STUDY THE }
$$

EFFICACY OF BHUMYAMALAKI 
$\begin{array}{lll}\text { MULA CHOORNA ON } & \end{array}$ RAKTPRADAR(MENORRHAGIA) " we will be used choorna (powdered) of bhumyamalaki mula with tandulodak (rice water) orally.

KEYWORDS: Raktpradar ,vata\&pitta dosh, bhumyamalaki mula,

\section{INTRODUCTION:-}

PRADAR due to pradirna (excessive excretion) of raja (menstrual blood), it is called as pradara \& since ,there is dirana( excessive excretion) of asrk (menstrual blood) hence, it is known as asrgdara. This conditions may arise due to the imbalance of the hormones which is caused by the aggravation of vat \&pitta dosha. Blood tissue is considered as one among 7 dhatu as per Ayurveda. Blood is related with pitta dosha. Hence, bleeding disorders are usually influenced by pitta imbalance.

A normal menstrual cycle is 21-35 days in duration, with bleeding lasting an average of 5 days and total blood flow between 25 and $80 \mathrm{~mL}$. Heavy menstrual bleeding is defined as total menstrual flow $>80 \mathrm{ml}$ per Bleeding in between menses is also abnormal uterine bleeding and thus requires further evaluation.

The start of menstruation during puberty and the length and regularity of the menstrual cycle is controlled by hormones produced in an area of the brain called the hypothalamus, as well as by the pituitary and adrenal glands.

Heavy periods, menstrual bleeding are due to many physiological \& pathological causes. Many factors such as hormonal imbalance, mental condition, diet, lifestyle contribute to these menstrual problems. Menorrhagia is the technical term for the prolonged uterine bleeding. Uncontrolled uterine bleeding or excessive menstrual bleeding is also termed by this name in few of the instances.

Complications of heavy menstrual bleeding could also be the initial symptoms. Excessive bleeding can lead to anemia which presents as fatigue, shortness of breath, and weakness. In pathogenesis of raktapradara rasa, rakta \& vata dosha are main responsible factors. Bhumyamalakimula choorna with tandulodak plays an important role to alleviate this pathology \& effectively controls the bleeding.It is also help to cure the complication which occur due to heavy uterine bleeding. we have to study the combination of bhumyamalakimula choorna( powder) with tandulodak (rice water) orally as per mentioned in Bhavprakash Samhita .

AIMS AND OBJECTIVES:- 
Aim:-

To study the effect of bhumyamalakimula choorna on raktapradara( menorrhagia).

\section{Objectives :-}

To study efficacy of bhumyamalakimula choorna on raktapradara. (menorrhagia).

\section{MATERIALS AND METHODS :-}

1. Literary information about the study has compiled from ayurvedic texts.
2. Various publication, text books, research papers has considered to collect the literary material.

3. For all the procedures various ayurvedic text are referred

Choorna of root of bhumyamalaki with tandulodak (rice water) prepared according to Bhavprakash Samhita, concept of preparation choorna take from sharangdhar Samhita.

\begin{tabular}{|l|l|l|l|l|}
\hline Sr. No & \multicolumn{1}{|c|}{ Content } & \multicolumn{1}{|c|}{ Latin Name } & Family & Part Used \\
\hline 1. & Bhumyamalaki & $\begin{array}{l}\text { Phyllanthys } \\
\text { Niruri }\end{array}$ & Root \\
\hline 2 & Rice & & & \\
\hline 3 & Water & & & \\
\hline
\end{tabular}

\section{PREPARATION OF DRUG:-}

The powdered of root of bhumyamalaki with tandulodak (rice water) will be prepared according sharangdhar Samhita.

\begin{tabular}{|l|l|l|l|l|l|l|}
\hline \multicolumn{1}{|c|}{$\begin{array}{c}\text { Sr. } \\
\text { No }\end{array}$} & \multicolumn{1}{|c|}{ Content } & \multicolumn{1}{|c|}{ Rasa } & Virya & \multicolumn{1}{|c|}{ Vipaka } & \multicolumn{1}{|c|}{ Guna } & \multicolumn{1}{|c|}{ Karma } \\
\hline 1. & Bhumyamalaki & $\begin{array}{l}\text { Tikta, } \\
\text { Kashaya } \\
\text { Madhura }\end{array}$ & Sheet & Madhura & $\begin{array}{l}\text { Laghu } \\
\text { Ruksha }\end{array}$ & $\begin{array}{l}\text { Kaphapitta } \\
\text { Shamaka }\end{array}$ \\
\hline 2. & Rice & & & & & \\
\hline 3. & Water & & & & & \\
\hline
\end{tabular}




\section{DISCUSSION:-}

Ayurvedic medicine are designed to balance energetic, emotional, mental, physiological and immune responses of the individual to ensure long-lasting and permanent relief. Ayurvedic medicine stabilize hormonal imbalance and improve the uterine tonicity. Ayurvedic medicine not only reduce profuse menstruation, but also help the body to restore its normal physiological cyclical rhythm of menstruation.

Powder of root of
Bhumyamalaki with tandulodak (rice
water) should be orally given in th raktapradara. Due to bhumyamalaki rasáTikta Kashaya \& madhura its acts on pitta dosha, guna-laghu, ruksha and its raktagami \& kaphapittashamak properties bhumyamalaki acts on raktapradara .

\section{REFERENCE:-}

1. Prof. Premvati Tiwari, Ayurvedic Prasuti Tantra Avum Striroga, Chaukhambha Orientalia, Varanasi, Reprint 2014

2. D. C. Dutta, Textbook Of Obstetrics, New Central Book Agency (P) Ltd., Kolkata Seventh Edition.

3. Brahmanand Tripathi, Sharangdhar Samhita, Chaukhambha Prakashan, Reprint 2012.

4. Prof. Dr. A. P. Deshpande, Dravyaguna Vijnyana Part 1 And 2, Proficient Publishing House, Pune, Reprint July 2010.

Cite article:

"To study the efficacy of Bhumyamalaki Mula Choorna on Raktapradara (Menorrhagia)." Ankita Ashok Thakur, Seema Mehere Ayurlog: National Journal of Research in Ayurved Science- 2019; (7)(1): 1-4 